\title{
An-Arché as the Voice of the People: Jacques Rancière and the Politics of Disagreement
}

\author{
Žarko Paić \\ Department of Fashion Design, University of Zagreb, Zagreb, Croatia \\ Email address: \\ zarko.paic@ttf.hr \\ To cite this article: \\ Žarko Paić. An-Arché as the Voice of the People: Jacques Rancière and the Politics of Disagreement. International Journal of Philosophy. \\ Vol. 7, No. 1, 2019, pp. 1-16. doi: 10.11648/j.ijp.20190701.11
}

Received: November 12 2018; Accepted: December 13, 2018; Published: January 19, 2019

\begin{abstract}
An-arché in the thinking of politics and aesthetics beyond the tradition of "political philosophy" of Leo Strauss and Hannah Arendt in 20. century, or in contact with the ideas of political emancipation by Joseph Jacotot, and Karl Marx and anarchism, marks the theory of politics as a disagreement (mésentente) in the writings of Jacques Rancière. The intention of this text is to show how and in what way the thinking of the political should confront to the philosophy of politics who always take care theoretically about the politics of norms, postulates and rules of action. Since Rancière believes that political preceded by politics as a police or regime of the oligarchic law in contemporary liberal democracies, and it should be a matter of radical equality among citizens, then it is the fundamental problem of determining politics in an attempt to think of anarché. In this contingency, we are doomed to a constant struggle with the order of inequalities and chaos in its own vagueness. That must be a reason why we use the word "mysticism" for what comes out of the state in-between two ways of comprehending a politics: (1) as the power of a hierarchically predicated society on which a state is constructed and (2) as a spontaneous struggle for democracy. The true politics of the equality must face what lies in its own bargain. And that is the powerful and chaotic an-arché. The paradox and aporia are not that democracy and freedom are derived from this principle without principles. Anyway, the scandal that rules in neoliberal oligarchy represents a confirmation of the same an-arché. For this reason, its archi-politics, para-politics and meta-politics are "the cunning of reason" of a perverted order of the world where the power of the "police" sets limits to the "politics" of freedom and not vice versa. Contemporary oligarchy is based in this an-arché-ic model of chaos and ambiguity in all its visible and invisible areas of action, from the management of the economy to marketing policy. But the problem with Rancière's metapolitics has been seen from the beginning to be a problem of the impossibility of political without the articulation of power. Equality without power remains unfulfilled by the demands of the "people" as temporary demos.
\end{abstract}

Keywords: An-arché, Oligarchy, Democracy, Disagreement

\section{Introduction}

Why do we have a certain kind of manner to say very often that today anything has become political and that almost everything is happening as aesthetic body shaping? Do that two terms contradict, though it may be that behind Janus' face masks conceal the abyss of other definitions except what suspends any possible over-determination? It should be said that politics designates the power of ruling the people in the community (politeia, civitas dei, republic, monarchy, democracy). Aesthetics, in turn, signify the area of pure bodily experience of what belongs to the language and the image in the experience of beauty. We are not talking about feeling but on the experience. The difference is that feeling denotes a subject of psychology. In addition, the former and the latter shows to us the relationship between the work and the observer. As an experience, we call a reflection of feelings at a higher level of perception. Politics as power and aesthetics as an experience are not in contradiction with the determination of what enables them. It is impossible to impart the power without a sense of sensible experience. The relationship between the two should be causal and efficient. However, the problem arises when their connection is called into question. It no longer determines politics as power or aesthetics as a meaning of sensation in the world, but it surely comes with the emergence of a completely different 
"politics" and "aesthetics". On the other hand, abodes of "power" and "sense" are changing. However, it seems obvious that a different relationship becomes a daily experience. It might call that situation as an event of unfoundation action. Greeks named this by a word an-arché. The thinking after Heidegger, beginning with the ethical revolution in the work of Emmanuel Levinas, one can thus call post-foundational theory or deconstruction of the unconditional principle of "nature" of Being as presence, the idea of God and all that had features of the onto-theological tradition. [1]

An-arché in the thinking of politics and aesthetics beyond the tradition of "political philosophy" of Leo Strauss and Hannah Arendt in 20. century, or in contact with the ideas of political emancipation by Joseph Jacotot, and Karl Marx and anarchism, marks the theory of politics as a disagreement (mésentente) in the writings of Jacques Rancière. What should be especially emphasized right there refers to equality, which in many respects belongs to the mainstream of French political ontology of events, regardless of the differences between Derrida, Foucault, Deleuze, Lyotard, Badiou, Lefort, Nancy, and Lacoue-Labarthe. But the fact is that only Rancière has performed the most persistent criticism of the contemporary era of global politics as the oligarchic order of "police" rule. However, he gave a pretty convincing argument about that way of approach with a number of new concepts. [2] If we would like to make a card experiment according to thinking of politics today, we could show that "poker aces" with regard to the issue of this post-foundation event, which opens the possibilities of change of worldhistorical revolution, that is, from the typical French tradition, are present in the following way. All the basic concepts with which the modern revolution started were the notions of the French Revolution. These are equality, fraternity, freedom (egalité, fraternité, liberté) and last but not least - justice. The first term denotes the point of thinking of Jacques Rancière, and the third is associated with Foucault and Deleuze, the fourth with Levinas, Derrida and Lyotard, and the media intervention in the new historical framework. One can even argue that the term might be a key to its maintenance. The reason is that the concepts of the upcoming community of equality, freedom and justice are constituted here. The fraternity denotes exactly what Plato called the friendship (philia), and Aristotle the power of public action in the political struggle of equal and free citizens. One of Derrida's recent writings of ethical-political deconstruction, The Politics of Friendship develops very notion of experience as a political sense of community or solidarity. Without it, the upcoming world should be reduced to mere survival in the "dehumanized desert". [3]

What is left of contemporary thinking in this aspect of the disappearance of the metaphysical foundation of politics? We must not forget that Rancière's intervention takes place even before the "big turn". This happened, of course, about the 1990s and had an impact on the recent texts on politics and aesthetics. Dealing with the neoliberal triumph of the global order, the euphoria of consumerism in the modern societies of the West, the end of communism and the "return of political philosophy" essentially determines the direction of his late theory. [4] The issue that arises is even more paradoxical to the question of the "remaining" of the political one at the time of its transformation into the technical management of "crisis". It comprehends a politics in the neoliberal reduction of its essence to the contents of the economy. The reading, therefore, sounds like this: why does politics in the age of scientific-technical nihilism become mystical in the following turn from the fact of the upcoming event? The backbone of all agendas to the concept of action and the possibility of changing the historical-metaphysical notion of the world is undoubtedly Martin Heidegger. His late thinking in which the notion of event (Ereignis) appears as a sort of attempt to overcome metaphysics and nihilism of technology is by no means an unambiguous way to the political and politics at all. Although it has become impossible to differentiate his "ontology" from "politics" as they have recently shown many critical contributions, [5] it should be obvious that Heidegger did not make the concept of politics out of his own sense of meaning, irreducible to the relation to economics or science and culture, as Carl Schmit did, in particular, with his political theology. [6] It is well known how devastating ended Heidegger's' failed adventure with Nazism as a political event able to establish a "second beginning" [7]. If the metaphysical assemblage is at the same time determined to be an apparatus of Gestell, that is, from what is not an authentic way of living in the community, it denotes a vulgar way of showing the truth of the Being, then a paradoxical turn we could see precisely in that which all the French followers of Heidegger, even those who explicitly refuse to think it, and one of that is certainly Rancière, their thinking is represented as a late political debate where politics determine the thinking of new authentic event. Access and differences are unquestioned. But the closeness to the search for a new concept of politics represents "faith" in the possibility of an internal turn of a complexity. This happens even when it seems clear that this faith is still the utopia of secular "political theology". Undoubtedly, in this lays the impossibility of radical opportunities for action in the area of the existing real world of liberal democracy and global capitalism which belongs equally to "believers" and "infidels".

Rancière, thus, articulates thinking of politics as the field of absolute equality, because just equality as such constitutes the "essence" of democracy. For an-arché in a new context, there can only be "disagreement" and "dissensus" with respect to the ruling paradigm and their policy concepts at all. If the event of what is escaping the logic of founding a policy is related to criticism of power and experience, or politics and aesthetics as the relationship of something that is already essentially established in itself as a power-experience of naturalizing the order of leading ideas of history, then Rancière considers this thinking concerning the egalitarian turn of history. The West can be considered, thus, as a double operation of the categorial performing. It is above all the growth of the Platonic-Aristotelian logic of history in the 
field of politics as power and the modern science of beauty and excellence in the field of aesthetics as an experience. But every activity of growth is already an attempt at "new foundations". In the other horizon of history, the rules of the game might be different. The mysticism in the "essence" of this two-way event should be paradoxical and at the same time incomparable to the thinking of Jacques Rancière. The reason is that we might presuppose how an-arché has no fundamentals either inside neither outside. In this contingency, we are doomed to a constant struggle with the order of inequalities and chaos in its own vagueness. That must be a reason why the word "mysticism" can be applied for what comes out of the state in-between two ways of comprehending a politics:

(1) as the power of a hierarchically predicated society on which a state is constructed and

(2) as a spontaneous struggle for democracy.

In this article, I will try to explain how the thinking of political and policy in Rancère's writings becomes also the question of the boundaries between the philosophy of politics and the new theory of radical political action.

\section{The Question of the Method}

This difference is "ontological" and getting on the Rancière's distinction between two ways of community's essence. Without this one cannot understand his thinking of the political and politics. Politics denotes the activity of an authentic struggle for freedom and equality in the community, and the "police" is order or regime as a form of state. [8] The principle of democracy is not governed here, but that which is completely opposed to it. How do we approach this almost "Manichean" dispute, an-archaic conflict of an authentic event of freedom with a vulgar set of necessities of technocratic control in the democracies, as Rancière calls it oligarchic in the book Hatred of Democracy?

"We do not live in democracies. Nor, as some authors argue - because they think we are subject to the biopolitical rule of exception law - we do not live in camps. We live in the states of the oligarchic law, in other words in countries where the power of the oligarchy is limited by double confirmation of the sovereignty of the people and the freedom of individuals." [9]

It was already said that the approach to the understanding of Rancière's theory of politics represents, on the one hand, the critique of "political philosophy" and its return, and secondly, the re-definition of everything that is established by a categorical order precisely in this tradition. An-arché must not be taken as the quasi-transcendental principle like a weak signifier of a different historical course of politics and aesthetics. If the oligarchy and order signify the real condition of the state, then it denotes the impossibility of fulfilling democratic principles in the line of liberal democracies. In other words, minority rule largely does not support the argument that democracy has become an undermining of its original "essence," so it might have been possible to fix some external measures, such as improving the electoral system, for example, by preferential voting within party lists in representative democracies of the West. Quite the contrary, there is no original "essence" of democracy, no eternal or unchangeable "nature" to which the rule of the people relies on. The problem that follows is for Rancière connected by ontological and political nature. If the subject of democracy should be a nation as demos, then its "general will" of equality can no longer be transferred to elected representatives or direct deciding by the people as in ancient Athens or in the Italian medieval towns and Swiss small cantons, where at referendum citizen replaces the complex procedures of decision-making in the system of state government. Is there any alternative to these binary oppositions of the immediate and indirect government of the people? Do we always choose only between the same with quite different features?

The problem is that democracy means the rule of all as most (polloi) equal and free. It is also a rule without a subject and a rule that determines what the sovereignty of that is true without foundation. Why is democracy without a subject? It might be because the subject is constantly reconstituted by its political action. Therefore, a major problem in Rancière's thinking of politics is, it seems, that the basis of his theory of political called a disagreement (mésentente) lies in the non-political notion of equality. In order to bring equality to reality in the state, it must be subjectively politically subjugated to acts of rebellion against the "police order". Barricades are not just in the streets. They should be the necessary boundary between two worlds that are not irreconcilable. Instead, we should always be talking from the perspective of the egalitarian policy of "disagreement" and "dissensus" as constitutive terms for politics within the limits of liberal democracy. Paradoxes and aporias of democracy arise from its irreducibility to the "nature" and its "laws". If there is no first cause and the ultimate purpose, then everything should be seemingly arbitrary, contingent and selfdefining. Demos does not mean the abstraction of a particular subject or the arithmetic sum of adult people in the political community. Simply, it denotes a subject without substance which should be constituted in fracture from the notion of natural necessity as postulated by the realms of the rule of one (monarchy) or minority (aristocracy and oligarchy) according to the inherent features of the natural inequalities of people. Plato is still discussing those things in Republic. [10] What is paradoxical and aporetic should be that democracy, according to Rancière in his critique of Plato's "political philosophy", in itself has represented an exception and a scandal. We know that this could be possible only when the notion of equality and freedom can no longer be founded on the basic assumptions of the self-governing of political people. Rancière must, therefore, foresee that anarché represents another way of sovereignty and power from the historically established tradition of "order" of value. Of course, it might be only in itself obvious that 
this second direction of thinking of politics must be both aesthetic displacement of politics and the political displacement of aesthetics. [11]

The body in freedom and equality with Others in the community does not acquire subjectivity from the a priori rationality of political discourse. This type of opinion on the perspective of persuasion is Habermas's communicative or deliberative democracy. It has the power of dialogue in parliament and society as a space for political decision-making. [12] Rancière rejects this, of course, with the argument of the existence of "dissensus". However, this is the way in which politics should be performed in democratic life because parliament and the public cannot be the exclusive areas of politics. The body of political life requires an attempt to overcome the abyss between social spheres of dissymmetry. The problem occurs whenever in the modern ranking of political communication the market becomes the only place of mediation and the only measure of democratic equality of opportunity. If the state does not originate from society, then neither does the nation create a state, as it is shaped by the tradition of German state law and the theory of sovereignty. Against the liberal and antiliberal ideas of the freedom of the individual and the sovereignty of the people Rancière goes on to criticize the concept of politics as "police". By calling into question the republican ethos of the country as a "social contract" of Rousseau to the present contractualism, he also shows that both concepts are obsolete. In a confrontation with the challenges of neoliberal globalization of the world, it is necessary to build new approaches. The sovereignty of the people no longer has its own signifier. When the "people" are replaced by the rule of the oligarchic elite, the question arises of competences and knowledge for performing complex public affairs. Administrative management replaces the political participation of citizens. Individual liberties, though, are the basis of market economy and the value of "democratic individualism". But these values are equally nostalgic for the past. In the new order of reign, the "freedoms" (liberties) are replaced with competencies of talents in the strict competitive struggle for social recognition. As politics in the sense of the state order and community management lost the primacy in favour of economics, in the same way, the aesthetics at the end of the twentieth century has been set in an uncomfortable situation. Searching for its bargain "basis" of sensitivity instead of autonomy it has become the service of technosphere. Without absolute equality as the unconditional act of the democratic principle, an-arché politics become the "police" as regime and aesthetics in an encounter with the regenerated art. During the reign of the image, it addresses to "emancipated observer". So, a rebellion against the order of the "beauty" and "sublime" with the subversion of "sense" rather than any new canon forms the aesthetic displacement of current contemporary art. [13] What is, exactly, in the politics the term "disagreement" (mésentente), this should be the "dissensus" in the aesthetics. But with the addition of a political predecessor to aesthetics, the "dissensus" is, finally, a continuation of disparity with other means. In both cases, Rancière wants to cancel the trust of governing systems as a political agreement between the subjects/actors of neoliberal oligarchy, and all that follows in the aesthetic field of perception, where rationality becomes a conceptual diagram of technosphere, while pleasure in spending replaces creative anxiety of producing.

In short, this premise seems to be appropriate. Rancière's works devoted to politics and aesthetics can be understood from the perspective of critique of the largest possible perversion of modernity: that, in fact, we do not live in democracies but in oligarchic states. If we should agree with this assumption, then neither "politics" nor "aesthetics" are valid answers to the problem of the end of the metaphysical image of the world, as well as the disintegration of the historical assemblage of the BeingGod-Human-World. That are just two expressions of the same discomfort. But what so dramatically affects the anarché thinking of upcoming events beyond the idea of "nature" and "order" in the political and aesthetic sense might be the inability to overcome the abyss. Because of this, the logic of the rebellion versus the political order of "oligarchic democracy" today is condemned to the childish illness of left-wing politics, and Rancière so radically calls that into question. These are precisely the politics of sovereignty and aesthetics of modern individualism. There is no return to the golden age of the ancien régime and lost innocence will not be revived anymore. When an entity is determined by action or struggle for self-recognition as a sans-part or one that has no share in ownership, such as the ancient slaves and modern proletarians, then the only solution to the dispute between universalism and particularism is to move to the other coast. Sans-part must be eliminated or socialized in the process of a radical democratic revolution. Anything else is the vain effort to reach the "zero point" of radical thought. Being assessed, the spontaneous anarchist revolt that does not know what to do with the state and is aesthetically "mystified" ends like the unrequited sexual desire for the impossible sublime object. [14] Rancière, therefore, places the issue of the subject of the rule and its inability to establish itself in the sole centre of criticism of the oligarchy as a form of state in the global order of capitalism. It does that through what he called the institutional governance of the regime or the "police".

Instead of a subject that is pre-constituted by the mind in "political philosophy" from Plato to Kant, we have a process of subjectivization. It is a process in the discoursepolitical event of emancipation. The alternative to the mind cannot be settled down in passion and agonism. The subject, on the contrary, is politically constituted through the action of subversion of the existing order but not through the abolishment of the state institutions in the liberal democracies and its fundamental principles of civil 
liberty and equality before the law. The question of access to the thinking of politics seems to be the question of the method during the rule of the principle of an-arché. It might be significant to approach the thinking of the anarchic and egalitarian turn in an era no longer preceded by the continuation of history in the sense of ultimate purpose and meaning as it has been appropriate to Hegel's speculative dialectics of the Absolute. The method is no longer a "royal way" of the subject to the truth. When the head was symbolically cut-off from the king, then the return of politics can no longer be comprehended by the mere return of anything that was relevant to the modern notion of the state, politics and law. Without the sovereignty of the nation-state, there is no sovereignty of the real subject of politics. It needs to be re-created on other "foundations" or replaced by another "noble lie" about the emergence of the community like a well-known Plato's mythical story of metal divisions according to the times of philosopher-kings, warrior-guards and farmers-tradesmen sought to strengthen an ideal community (politics) in the Republic. Gold (theory), silver (praxis) and iron (poiesis) are divided according to natural and other criteria of inequality and order of rank in society. Quasi-fiction or myth about the political order on the basis of the hierarchy of art in the human (political) community since then has the goal of metaphysical justification of inequality in the construction of the historical world. This is what Rancière believes is the political and aesthetic formation of illusion when the dissensus is debated through archi-politics and parapolitics. [15] Therefore, this political thinking denotes also methodically anarchic and systematic assemblage in its playful combination of new concepts. What and who is the subject of Rancière's politics of emancipation? Is it demos in the meaning of a modern political nation as citizenship in existing political areas, or perhaps an emancipated class of unrecognizable people who ask that what belongs to the contingency which becomes the universal necessity of the historical survival of mankind - equality? If it is the former, then why Rancière does not take into consideration its real qualities and defects but postulates the subject of mystical rebellion against the "police order" of modern technology and its way of the oligarchic rule with the rationality, competence and expertise of the meritocracy? If the latter is right, how does this abstract totality of struggle for the particular recognition of the "class" of the sans-part can truly be established without the simultaneous transformation of the Other, beyond the class-social hierarchy of society in the age of global capitalism? The question of the method, in this case, points to the issue of the relationship or contingent relationship between the politics and the aesthetics of the subject that in its mystic rebellion and the subversion of value remains an empty marker if there is no criticism of the quality of its propulsion. Can such an understanding of politics and aesthetics respond to the real challenges we are faced today in a complex daily practice?

\section{Politics as a Disagreement}

What is politics? To Rancière, against the main line of political philosophy, the science of politics and sociology of politics, it doesn't mean the "execution of the power," as we can read in the first of the Ten Thesis on Politics. [16] Instead, politics needs to be understood from its irreducible "essence" as a "mode of specific action" by which the subject is left to mark its own aspirations, desires and feelings. [17] From Lacan's Ethics of Psychoanalysis through Althusser's Reading Capital to Foucault's lectures on the hermeneutics of the subject, a series of attempts have been made to a new notion of the subject. Rancière also fetches it on this wave. We can add Badiou here because he does it also in the way that the subject considers the process and the event of the emergence of the new. So, the question of a subject in this context might be always an issue of emancipation. And since it is a political category of establishing what has been neglected or since the very beginning has appeared as a lack in the very concept of politics, then the relation between politics, emancipation and subject must be sought on other ground beyond the "political philosophy" since Plato until to Leo Strauss. From this it might be obvious that politics does not belong to the second rank of the terms, even though through the course of history of the Greeks over Rome and the modern world to the global order of the late 20th century - its own peculiarity has been suppressed to the strength of other areas of human activity such as economy, technology, the science and so on. The thesis which has been performed by Rancière has its origins in the political tradition of Carl Schmitt and Hannah Arendt. But the obvious difference is that Rancière explicitly refuses to admit that the main concept of politics should be the concept of power (pouvoir). Undoubtedly, power denotes something that connects with the politics, but it is not its "essence". Why am I writing the word essence or substance in the quotation marks? The reason lies in what Rancière as well as the whole stream of renewal of the notion of the idea of politics as an event of freedom, equality and justice - from the circle of French thinkers on the trace of Heidegger and phenomenology, poststructuralism and related theories - are based on assumption of the deconstruction and neutralization of classical or traditional metaphysics. From that framework, essence has been understood as unchangeability of conditions and permanency of relations. The stability of the category is no longer guaranteed. Inasmuch from Rancière's line of sight should be clear that this "way of specific action" of politics must demonstrate as decisive to the signifier or subject of its executing. The politics hence implies the contingent nature of self-determination. In a situation that is not entirely free, it should be already defined as a set of relationships and different rules of the game within a single discourse, politics acts as an emancipatory activity to the subject of "people" (demos). In other words, acting cannot denote an "essence" of politics. It should only be subjectivization. How? Simple. It allows a specific mode of action to become political. Not all in that assemblage hence become politics, but all at once 
become immersed in aesthetic and political assemblage, and like a nation as demos must continually re-constitute themselves. This is, of course, a revolutionary task because it acts as a struggle for equality of "conditions of possibility" of freedom rather than as "equality of chance" in the market. The concept of politics as emancipation and as egalitarian political-aesthetic turn of the notion of power to spontaneous rebellion versus the order - that's where its last limit stand.

That is, in fact, the specificity and difference between Rancière and other political theorists such as Chantal Mouffe and Ernest Laclau. [18] Thus, the effect cannot be explained by the existence of rational discourse nor by the agonistic passion in conflict with the order within the space of public discourse of politics. It is a pure contingency. In addition, in its unpredictability, it is open to overcoming the binary oppositions of modern metaphysics such as the remains of Descartes' philosophy (the spiritual substance vs. the bodily substance). Relationship signifies what adds to the subjecting of the feature of the political into the process of emancipation from "nature" and "necessity" as always to the existing order of social inequality and hierarchy. It creates a fertile ground for the rise of the oligarchy at the very beginning of Athenian democracy. Philosophy does not apply to politics as the mind against the body in the Plato's-Descartes' perspective. Rancière starts from the fact that what is emerging in the world as a political has represented a unique contingent event. It follows that nothing is predetermined neither can its ultimate purpose and goals be determined without the emergence of "nature" and its "laws". Politics can no longer be a means of increasing power or, indeed, something that is economically viable for the state and society administrative management of the new era. Its autonomy is by definition democratic. For this reason, equality in its universality and particularity denotes its condition for the emancipation of man in its present order. Let us consider more closely the notion of the "condition of possibility". Kant's three critiques - of the pure mind, the practical mind, and the power of judgement - appear to be familiar to the modern way of thinking. Undoubtedly, we have here modal categories. They are logical and directed towards the notion of time as a continuum of fragments of past, present and future: the possibility, the reality, and the necessity. When it comes to the "condition of possibilities" of emancipation - and that expression Rancière used synonymously with the concept of egalitarian policy - we are always dealing with a contingent condition. It is not the opposite of "necessity", but a specific possibility that belongs only to political and politics in the meaning of the "police order". And since Rancière follows the logic of Marx's radical politics of emancipating a universal class, such as a working class struggling for its own recognition as the universal recognition of man's equality, it is possible to say that the "empire of freedom" determines the existence of the "empire of necessity" only with the overlapping logical-historical order.

Freedom thus no longer appears in the anti-essentialist sense as the first assumption of the necessity of its seriousness in the real world. On the contrary, for Rancière the "condition of possibility" of contingent freedom in the world of "police order" is precisely what makes "democracy". So, that represents the concept of absolute equality of every person with each other and not, therefore, of the multitude (not a people in terms of polloi, but demos) which govern over the minority. Instead of quantitative or arithmetic definitions of the democratic order as a form of rule, it is a logical turn in the notion of the political as the "conditions of possibility" of politics. No contingent "cause" produces a secondary consequence except than the efficient cause which comes from the fact that democracy as a scandal and an excess cannot establish anything else, especially in the notion of reign and power, because of the rule of the people as demos. Undoubtedly, the people are not pre-determined initial of anyone, or by cultural criteria. It denotes a subject who is constantly subjectively different. This means emancipating from incomplete and deficient emancipation."

So it is that scandalizing men of substance, the demos, that horde who have nothing, become the people, the political community of free Athenians, the community that speaks, is counted, and deliberates at the assembly, causing wordsmiths to write, it has pleased the people, the people have decided. For Plato, the man who invented political philosophy for us, this formula easily translates into the equivalence of two terms: demos and doxa: it has pleased those who know only those illusions of more or less that is called pleasure and pain; there was simple doxa, "appearance" for the people, appearance of the people. The people are the mere appearance produced by the sensations of pleasure and pain manipulated by rhetoricians and sophists to stroke or intimidate the great animal, the morass of folk who have nothing, gathered together at the assembly. (...) Politics begins with a major wrong: the gap created by the empty freedom of the people between the arithmetical order and the geometric order. It is not common usefulness that founds the political community any more than confrontation or the forming of interests. The wrong by which politics occurs is not some flaw calling for reparation. It is the introduction of an incommensurable at the heart of the distribution of speaking bodies. This incommensurable breaks not only with the equality of profits and losses; it also ruins in advance the project of the city ordered according to the proportion of the cosmos and based on the arché of the community" [19]

The problem faced in this set-up of the category is, of course, ontological-political, and not just the result of historical development. Rancière must now, from the outset, turn off the action of ontology - the alliance of philosophy and politics - as the power to rule the idea of the very reality of the event itself. In order to do so, it is necessary to have an understanding of Plato's idea of community (politeia) and the modern turn in which the economy takes the place of politics by suppressing freedom and equality in the area of the capitalist ideology of the market, profits and "equality of chance". Rancière, therefore, in his critical accomplishments of the term an-arché must reach the openness of the political phenomenon without any external purpose. The same applies to the aesthetic concept that is correlative to the political. It is 
a question of any future of politics, therefore, aesthetic and vice versa. The reason for that is the fact that the traditional categories of theories, praxis and poiesis (knowledge, action, and production) from Plato and Aristotle have been greatly altered. Marx is at the centre of a practical relationship with the world which means that every practice is also a political act of change of an existing condition, and every production of life presupposes knowledge of the possibilities of change. On this trace as well as a series of related attempts, from Deleuze to Badiou, Rancière considers politics as a practicalproductive activity, or as a political-aesthetic subjecting of man within the limits of the human being at large.

In the writings of the 1990s, such as Disagreement: Politics and Philosophy, and a minor manuscript Theses on Politics, we can see a critical reading of the idea of "return to politics" and the "return of the political philosophy" of democratic approach to politics as egalitarian action of people (demos and people), political subjectivization and, finally, the relationship of politics and aesthetic, which will especially be the subject of the book Le Partage $d u$ sensible published in 2000. It might be evident that the relationship between philosophy and politics for him is no longer a matter of guiding the idea of reality because this is not feasible in terms of Platonic-Hegelian metaphysics. Politics for Rancière, however, cannot be the philosophical selfreflection of event that is happening as it does for Badiou. [20] Simply, it is not the thinking of the event. Under the title of the most important Rancière's book, disagreement sufficiently illustrates this relationship: Politics and philosophy. The order has been changed. This means that policy can no longer be considered an issue as a signifier of the absolute requirement for infection with a "power" naming and legalization system of binary oppositions through history. Politics can only be conditioned by "philosophical" activity. The reason lies in the fact that it disqualifies every ranking and inequality. Its "essence" is placed in an unprecedented event. Thus, we are faced with an uncanny act of going beyond the "nature" and "necessity" framework. Politics appears in the world as well as freedom in the sign of the power of that uncanny irreducible an-arché.

What does it mean and what is determined by that concept? Is it fit for any radical democratic politics that will not remain on the level of utopia and the unexpected expectations of the real possibilities of political today when neoliberal global capitalism is realized in the world in a way of strategy, ideology, discourse and management of a "rational election" without alternatives, from which it is necessary to emerge, which Rancière himself explicitly claimed in his main statement in the book Hatred of Democracy, "that we do not live in democracies, but in oligarchic states"? An-arché might not merely be suspense and neutralization of the notion of a foundation of politics in its philosophic source in Plato's Republic, Statesman and Laws. If it were just that, we could only talk about a new reading or critique of Plato's and the notion of the philosophy of politics. Such a reading may be closer to the intentions, for example, of what Hannah Arendt did in the demand for the theory of political irreducibility. Even the name and the notion of un-foundation refers to the act, and not to the "nature" and the category of "law" derived from it. And from them follows the ranking and social inequality justified by the metaphysical reasons for the existence of God and the necessity of the monarchy, the aristocracy and the oligarchy. An-arché hence cannot be by analogy the first activity, principle and category with which it begins to initiate a process of Being as becoming. What comes out of that notion might be mysterious and equally uncanny. It is the singularity of the event of the rule. Such reigns are neither determined nor limited, nor are they reduced to something beyond themselves. The only problem arising from that it can be neither term, not a principle of starting, but only "condition of possibility" that "way of specific action" which requires that the demos for its vote chooses itself, not some higher signifier. God no longer appears through someone or somewhat. His voice becomes directly the voice of the people. So, instead of monophony, we can hear the echoes, polyphony of voices from the depths (de profundis).

Tragically in the notion of democracy should stand, thus, that freedom denotes an irreversible destiny of man. It cannot be avoided. Sartre defined the freedom of metaphysics in the existentialist turn of liberty by means of a project and a contingency: that is simply the same and cannot be otherwise than that! The paradox of freedom presupposes the necessity of its condition of possibility. That is a reason why a man is condemned to freedom, and existence is precisely that hole in the Being through which the course of action goes. [21] Nothing and event are correlative terms/words. Unlike that, freedom as a project of the upcoming presupposes determination and action in the direction of preserving its own "Being" that is not in what it should be but is completely different from the Being. This is that what might be determined as nothing and as a radical change of the condition of matters. Rancière in the book Disagreement and all other surrounding texts does not endlessly vary the thought of the reversal between the ontology of politics and the political-aesthetic event beyond that of ontology at all. An-arché introduces us to the world of political contingency. Anyway, its main concern encompasses the issue of equality. Without it, democracy as the rule of the people (demos) falls into the abyss of the oligarchic "police" order.

Already in the "Afterword" of Disagreement, the question of whether or not the principle of politics leads us to a problem (aporia) is discussed. This is the first assumption of Aristotle in his famous Politics. [22] Since our era should be characterized by double return, both "political philosophy" and "politics", we might pose a question what really marks the return of philosophy and politics. If Marxism has understood politics as an expression of social relations between capitalism and class struggle, and liberalism is an activity that must provide for the protection of the private property of an individual as well as his bodily pleasure in the sense of the good considered to be common, it should be obvious that this politics is overwhelmed with something inauthentic. Rancière believes that the roots of such a 
situation lie at the very beginning of political philosophy originating in Plato and Aristotle. Moreover, their notion of politics, in spite of the essential differences, derived from the core of the idea of Western metaphysics. And this is the idea of purpose (telos) and the goal of history. The eschatology of the idea of good in terms of the rule of freedom and justice, however, draws attention to the notion of equality. There is no doubt that it signifies just the thing which Aristotle determines as justice with the arithmetic concept of equality. Therefore, it is, much "more" and much "simpler" than the order, the taxis and the hierarchical arrangement of the art and the virtue of knowledge, action and production (theoria, praxis, poiesis). Instead of a priori setting, for Rancière it is no longer a matter of first causes and the last intentions of an unknown starter of all action (God?). Everything lies in the contingency of what is happening in its irreducibility and indeterminacy with external ends and goals. When the idea of the purpose of "nature" is abandoned as the hidden foundation of all inequality between people, then we come to this axiom of democratic politics at all:

"Politics is an activity based on the principle of equality." [23]

But what about "equality" here? Is this a non-political term of equality or a political one? It seems that from Rancière's perspective we must move in the following way. In the book At the Edges of Politics, much more attention is devoted to the attempt of exclusion of the concept of politics in its pure form from the logic of power. Anyway, it would be extremely difficult to say that Rancière in his intercession of the "mystic" of spontaneity rebelled against politics as the institutional order of the oligarchy's rule misses to see the extent of the action of dispositive power. His criticism of "political philosophy" with the terms of disagreement and dissensus, as we have already mentioned, is directed against the power of politics that in post-democracy rule today imposes itself as marketing mediation with the idea of market competition as a model for the policy of liberal "consensus". [24] In the Ten Theses on Politics, we are faced with an issue about the subject of power (kratein) and the reign of the multitude (ohlo-kratein). [25] If politics begin with the awakening of the subject of state and an-arché in the state of subjectivation using rational-discursive action against the agents or actors in the order of reign in the liberal-democratic system, the essence of democracy should be in constant challenge of creating a "nation". That might be a reason why it is not just what this word "equality" really denotes arithmetic, symbolical or qualitative. The first notion denotes a mere sum of magnitudes divided between individuals as the collective body. The second notion, indeed, relates to what Rancière says about the power of the people as demos in the struggle against the realm of inequality, unfreedom and injustice. Such regimes in today's of neoliberal globalization are those in which democratic consensus moves into populism and autocratic forms of governance. Finally, the third notion determines the "essence" of the democratic government of the ,people" as the subject to be constituted as always a particular-universal entity that is fighting for the truth. What is particularly significant should be that the incompatibility of the communication strategy of negotiations between the two - subjects of politics and actors of "policies" - becomes the event of emancipation. The three concepts of equality correspond to something which Rancière in his historical-philosophical critique of Plato's ideas of politics called archi-politics, para-politics and meta-politics. [26]

Demos is thus articulated in a contingent struggle. As a part of the "people" in the meaning of gender/sex identity, nation, class, only citizenship assumes the role of particular universality. Differences between human and civil rights are the differences between empty universality and content particularity. However, since Rousseau's concept of sovereignty of the people in the form of a Republican community (state) is crucial for distinguishing between ethnicity and demos in the modern meaning of these words, it is necessary to see the boundaries between the general will and the special right of those who are recognized by the law of birth or "naturalization" of citizenship. Emancipation takes on a revolutionary meaning only when its "bottom" raises to the "top". It also becomes a cultural (aesthetic) and political one because it signified a recognition of the one who is invisible, who are denied the possibility of speaking and who is in the position of Roman plebs or proletarian, and capitalist. Like all French postmodernists, so in Rancière's case, we can talk about the anti-essentialist mode of thinking. By that, I'm not talking of the dialectical method of thinking as much as the rejection of the logic of overcoming/abolition (Aufhebung) in the synthesis of contradiction at a higher level. When this is absent, then the interpretation of Marx always comes down to the politicized version of the event of a revolutionary subject. This is even a feature in a case of Althusser's epistemological cut. Althusser, namely, used this concept taken and derived from the works of Gaston Bachelard to understood Marx as ideologue and philosopher with the notion of the alienation of labour in the period from 1842 to 1844, which ended with an Economic-Philosophical Manuscripts, and from 1845 and the German ideology as scientist in the form of critique of political economy and sociology. [27] After the totalitarian experiment of the 20th century, in which Marxism served as the ideological cover of Stalinism and other related systems in the liquidation of freedom, it can no longer continue with the idea of linear history to the final arrival of communism as the ultimate salvation at the end of history. That's a reason why in the case of Hegel we witness always the actions of un-foundation concerning the new metaphysics and related thinking paths in contemporary philosophy. Thus, the idea of "the end of politics" comes from the Hegelian obsession with the distinction between the political state and the civil society. What remains of dialectics can only be the thought of a differently structured totality. Sartre in the Critique of the Dialectical Reason has been performing the concept of detotalized totality. So, the origin of all the further accomplishments of the decay of the integrity of the whole metaphysics can be found in his late thinking. [28] The idea 
of dividing philosophy in the fields, as well as life itself on the "sectors" of spirituality, politics and aesthetics, represents a complete fault. Rancière, therefore, didn't let go of the conception of revolutionary struggle in the modern capitalism, nor did he agree to an agreement of the "end of politics " in the neoliberal "deal" of the current left and right in Europe. Rancière articulated, for example, his early views on the trace of Althusser's reading of Marx. [29] But the direction has been changed to the policy of radical egalitarian "mysticism" in the struggle for the subject. Concerning the mutual interests in the act of emancipation, it becomes a political entity or subject.

The question I ask here is the following. Is not the notion of "equality" as in all the other theories of postfoundationalist circles of politics left to the event of nonpolitical mystification of the riot? We know that it always ends in unavailability to cross the vicious cycle of the neoliberal axiomatics of global capitalism. The thing we should know is that it cannot find a realistic alternative to the oligarchic power politics. Therefore, it might be condemned to the powerlessness of inevitable consolation. When politics is no more a question of power, but rather that concerning the principles of equality, we have at work a leap into the utopias. Instead of reconciliation with survival on the edges of a "joyful dystopia" without end, we have been extradited to the upcoming event of emancipation as the micropolitics of anarchic rebellion. What are the paradoxes and aporias of Rancière's politics of disagreement? First of all, that term is not related to Lyotard's term "drift" (différend). [30] There is undoubtedly a close contact between two thinkers in the understanding of aesthetics and politics. Moreover, many will find in the two identical views on the political struggle against neoliberal capitalism and oligarchic method rule of the rich elite of harness financial and political power. Methods of fighting should be related to the anarchical way in the finding of a "new subject". The aesthetic line of politics in Lyotard and the political turnaround in Rancière speaks in affirmation of the fact that justice and equality are not merely correlative concepts of an upcoming community, but a specific way of asserting the truth in societies of absolute control. What determines the notion of disagreement is two: (a) la méconnaisance (ignorance or lack of understanding of the subject of dispute) and (b) malentendu (misunderstanding arising from the lack of understanding). [31] The conflict between these defective modes of discourse does not suggest that this denotes just the idea of politics as rationality, and man as an animal rationale (zoón logon echon). Political self-determination of man assumes this Aristotelian definition from Politics. The reason is that there is something "fateful" about human beings in the assemblage of action - the concept of community and the common good. It belongs to the "property" of that entity, which is called the people (demos). Rancière's politics of disagreement is directed against any form of fake and vulgar consensus on politics as power and the rule of the oligarchy. From this, it necessarily follows that political has ulterior primacy over the aesthetic (aisthesis) because the body is in its sensibility always defined by a common body of politics. This is not done as equality of citizens before the law, but rather as free people without any a priori divisions based on natural inequalities and titles. [32]

Disagreement can, however, be read as a critical response to Habermas's public consensus policy with the idea of the universal mind as a discourse in the political community. At the time of the publication of this most significant Rancière's book, Jürgen Habermas and American philosopher John Rawls have already a noted attempt at the last defence of the liberal-democratic order when it is already almost dogmatically established in the world. The doubt in its achievements has already been regarded as both Habermas and Rawls wanted to "establish" the political philosophy of liberalism "from below" by introducing those concepts with which contemporary politics and culture sought to overcome their results. This is primarily according to Habermas and his concept of communicative rationality, and in Rawls it is concerned by the concept of justice as "fairness". [33] In the situation of the multitude of cultural and life worlds of media formation, a new minimum consensus of subjects/actors in the space of political liberalism should be needed. Without this, democracy is left to the grace and failure of decay in all forms of anomie and oligarchic rule, but also in the anarchy of religious-cultural renewal of tradition. Instead of universality, the power of the special interest, almost in the US, brought into question the constitutional definition of the ruling culture on which the idea of democracy is based. In all those matters, multiculturalism was only an agreement - a "deal" - between the liberal state and cultural communities (minorities) as ethnos in plural societies of Western democracy. The crisis occurred immediately after the start of the era of neo-liberalism in the United States and Europe through the institutions of the state and the corporate-formed society. Rancière's response to the crisis of political liberalism - and his dilemma also - was that, instead of the metaphysics of justice and public consensus, from the politics of today we need exactly the opposite disagreement. In that notion, which seeks to open the problem of constituting a different opinion without referring to the fact that the arguments of "common sense" and fairness in the sense of a least fair game of plural participants with different worlds and cultures present the state of inbetween rational discourse (Habermas) and pragmaticidealistic appeal for justice (Rawls). Why did Rancière also open the real problem of the contemporary age with his theory of emancipation politics of equality and remain without solutions to his paradoxes and aporias?

It seems that the answer might be simple and therefore, in its simplicity, extremely complex. If in its analysis of the political and political structural analysis of the notion of power in all aspects of its manifestation the solution remains absent, it is comprehensible that the only true political strategy of emancipation will have to look for its answer outside the context of its own notion. Emancipation denotes the process of release from the bonds, whether they are real or symbolic, no matter whether it is gender/sex 
discrimination or class oppression, the intolerance of the nation or, rather, the subjectivation process in which an individual liberates himself as an individual from all authoritarian family spells, his own anxieties, and frustration. The act of emancipation is always a confirmation of freedom. However, it denotes a condition of any revolutionary policy. Hence the concept of emancipation, with which Rancière completes his analysis of the notion of disagreement and dissensus, is heading for the radical space of conquest of what has no foundation. [34] Freedom is without grounding, as Schelling has already shown in the dispute entitled Philosophical Inquiries into the Nature of Human Freedom. It is neither being nor the will, but the uncanny openness of possibilities of existence in the world. If emancipation is the "essence" of the political process of realization of freedom, of liberty, then what about the preoccupation with the concept of equality through the suspense of the concept of power as is Rancière's approach to politics?

The reason might be even more complicated because Rancière opens up the problem of a new notion of politics after the collapse of real socialism in Eastern Europe and the world in 1989 with the fall of the Berlin Wall. It doesn't seem necessary to emphasize that all the types of totalitarian rule after the October Revolution of 1917 had the concept of equality for their legitimacy. Of course, this legacy as a dark shadow follows the defeat of all the left-wing projects since 1989 in the world. In relation to the neoliberal strategy of economy-politics-culture as a rational consensus on the market, any egalitarian policy must first be deduced from two ideological reductions. The first is, as we have already said, the legacy of totalitarianism and dogmatic Marxism, and the latter is the rule of the oligarchic order in countries with a liberal notion of politics as representative democracy (freedom of choice, economic competition on the market, freedom of trade, and freedom of the press). With that in mind, Rancière's venture is in a proper way a search for a path between the two cuts, "subversive" as much as a futile effort to create an alternative to neoliberalism without reviving outdated paradigms of political thinking. But Marx, as the most important theoretician of capitalism and politics in modern times, cannot be thrown into the rubbish of history, mainly because his analysis of the concept of capital as a substance-subject of history represents a condition of the development of an equality politics without which contemporary democracy remains empty and formal. Hence the notion of equality in its "essence" becomes for Rancière the decisive one for any future emancipation of a man. This "egalitarian paradox" consists in the fact that it seems obvious in advance how any request for political equality would be meaningless if there was absolute social equality. [35]

The condition of possibility for any opportunities at radical political equality is economic inequality in society and its structural consequences. Rancière in Disagreement and other texts on this issue always takes his thoughts on the contemporary state of things in an analogy with the original Greek notions in Plato and Aristotle. However, his readings of antique texts cannot be hermeneutic, because it serves the function of performing the settings of the historical-structural relationship of strength. What Plato postulates in his Republic is no "ideal" state of relations between state and society. It is also the narrative of the ancient world and its ideological justification in its epochal capabilities. Equality, thus, cannot be derived from the idyllic consensus policy of the liberal democracies if simultaneously it does not pose what scandal exists in the real order, which Rancière calls with the term "police". Why? Just because the political equality, on the contrary, might be a condition for emancipation in the area of what he called the aesthetic distribution of the common good (communauté), and from which historically - from the antiquity to nowadays - we have ruled out the class without ownership, the sans-part (slaves, serfs, proletarians). This assumption should be the credo of the entire post-foundational theory of politics. Badiou named this assemblage the metapolitics of the event. If we were to translate that complete expression into the language of political struggle, then it would be a "communist hypothesis" without the pernicious legacy of Stalinist totalitarianism. [36] Concerning Rancière, however, the notion of politics as equality that determines the "essence" of democracy has its disengagement in the "mysticism" of anarchic rebellion against inequality, injustice and the ultimate line of non-freedom of man in the oligarchic states of the current global order. Hence, speaking of "the end of politics" and "the return of political philosophy" might be just another way of making the same apology: that, of course, equality cannot be said without the political re-articulation of power. There we also find hidden the place where politics finally no longer has its own origin in Marx's heritage, nor in the anarchist movements. Its place (topos) should be right there beyond the real power of politics. And therefore, in its "heroic" reaches, it is just another utopia of egalitarian powerlessness.

There are two perspectives on the "end of politics" as well as on the "end of the history". Former belongs to Marxist issues. It postulates communism as a future community of absolute equality. Politics, thus, lose the cause of its existence. The latter belongs to the liberal worldview. It aims to turn politics into management or control of social relationships based on the economy (and) rationality of the market. Both are paradoxically close and at the same time so opposed. In addition, both concepts of politics cannot be understood otherwise than as a means of establishing power beyond the reach of politics at all. That is a reason why Rancière in his late thinking has become the one who moves "on the edges" and between them showing us that the essence of politics must be equality and that equality becomes an-arché as the determinant of democracy. However, it denotes a step in the impossible demand for politics in large. But that impossibility does not arise from the inertia of demands in the contemporary constellation of political forces. On the contrary, 
impossibility designates the step inside the very core of this requirement, because it requires unavoidable, what precedes "nature" and "culture". The a priori must now become an axiom. This axiom will shake the whole order in which the understanding of politics as power is based. But the "egalitarian paradox" also should be aporetic. A just society - which must be based on inequalities - cannot be established, not because they are natural, but because the difference might be the identity of a person in a more profound sense of blindness to society and culture unless the first assumption of emancipation is fulfilled. It is, of course, political, and only with it the true history is born. In Greece, politics has always been regarded to be the highest practical activity. Its aspiration was to adhere to the idea of good and justice. We know that none of them can exist without freedom and equality. Emancipation, therefore, must necessarily be political. The reason for this is that only in this way its subject - the people (demos) is constituted. But since Rancière regards the civil society and the political state as an outdated way of functioning of the modern Western way of life, in the neoliberal concept of the rule that divide is overtaken in such a way that politics and culture become the means of a power to regulate social relations, and, of course, a new information economy with moving of the focus from the industry into the financial-speculative area of capital. Having this epochal turn in mind, it might be clear why this intervention in the theory of politics today attempts to open the question of the true subject of upcoming politics arising from all the noble dogmas of "political philosophy" from Plato to Leo Strauss. Although Rancière wisely despises to be a prophet or to repeat the gestures of his predecessors - from the egalitarian utopian as was Jacotot to Marx's vision of communism - what is undeniably him and what can't be deconstructed - using the Derridaen vocabulary - must be the idea of the common good (communauté). To whom "it" belongs, and what is at all such a "good" if, beyond the economicpolitical reduction of corporate capital management, the idea of a true community (politeia) cannot be founded in anything else, or in itself because it encompasses the uncanny power of an-arché?

\section{The Community of Equality vs. the Nihilism of the Oligarchy}

Some commentators of Rancière's viewpoints of politics argue his thought to be very provocative. [37] However, the provocation is not that we are confronted with familiar concepts from Plato to Hannah Arendt for reaching the "being" in the community. To the contrary, the provocation lies in what Rancière demonstrates: that the reason for today's "inflation" of the notion of political and politics in all areas of society, culture, art is due to living in the era of the total nihilism of the oligarchy as the order of discourse and order of the image. Such an order inevitably raises the rebellion versus the consent as an activity within the jurisdiction of the crushed political people. We don't, therefore, use the word "people" as people, but the people as demos for which no definitions of modern political history really exists. Since the people are derived from the modern theory of the sovereignty of the power of the overwhelmed king, and whose ritual murder represents the beginning of what Claude Lefort calls "empty space power", [38] and with which every new beginning of democracy must be faced, it might be clear that the very category of "people" has remained without its substance. A nation without sovereignty marks the age in which instead of the state as a place of political decision-making now the corporate governance of the global order occupies a real and symbolic place of political and politics. If there is no sovereignty, then the "people" are overwhelmed by the political meaning of that word. Or, in other words, people with no democratic legitimacy in the internal self-determination of the nationstate becomes a "multitude" (ohlos). It does not rule. In his place, the rule is in the hands of the financial-political oligarchy. In the previous order, the "multitude" was protected at least by the illusion of a powerful state and its principles of renunciation, and now the ground under its feet is lost as well as all illusions about the purpose and goals of history. Politicians will say that this is happening because of the fall of the welfare state or social state crisis at the end of the 20th century. The triumph of neoliberalism is mostly reflected in the fact that every account of the "golden age" of the ruling of this model of managing social relationships of late capitalism is considered nostalgic with no account for the time frozen in the past. Now is the time of social mobility, market competitiveness and innovative corporatism.

What can our thought do - descending from the heights of metaphysics to the ground of politics - in this nexus of problems? It can provide either new false hopes - reasons for fleeing into new utopias with new discourse of modernized building of the oriental gardens - or facing the underlying paradoxes and aporias of the present in the sign of the blind nihilism. The last chapter of Rancière's book Disagreement is titled "Politics and its nihilistic age". It deals with the performance of politics as equality in a democratic attempt to sift through all those terms that have become today a new rhetoric of the European liberal consensus: communion, differences, the universality of human rights. Rhetoric does not exhaust itself in proving one's own triumph, because the space of this policy is bounded by contradictions in real life such as non-communion, homogeneity, the particularity of civil rights within a nation-state. So, what Rancière considers most relevant to the true politics of disagreement as a politics of communion in the differences might be the absence of radical equality. Those who have been expelled from this "consensus" are sans-part. This is particularly noticeable in France. Moreover, it can be called paradigmatic to the problems facing the current condition concerning the European Union. As a matter of fact, the migrant population that is on the edges of the town, which, moreover, does not enjoy the same civic rights because it does not exist 
politically (sans-papiers or stateless people), undermines the big neoliberal consensus. So, the logical consequence of the loss of political rights in the modern meaning of democracy denotes the disappearance of humanity as the ethical voice of universal conscience. Instead of humanity and humanism on which the modern project of the universality of human freedom is based, the age in which we live has become a time of humanitarianism. This goes so far that the wars of America and the West have become "police interventions" in the global order, while the problem of refugees and displaced persons in the war zones is now called with the name "Humanitarian issue". Changing the discourse should always be accompanied by a change of the actual state. Thus, politics in the time of nihilism is not limited to humanitarianism. Its "police's" feature of neo-liberal "new world order" can be understood as a perversion of politics to ethics, and the perversion of policy to constitutional law, and that, in turn, decadently enjoys in its own delirium of normativism without any cover in reality. [39]

What can really oppose that? Rancière tries to comprehend politics as a matter of equality. The provocation is already that democratic politics do not hold power as a means of government but has in its hands the government as means of another worthy power. That power is related to democracy, and it always happens as a struggle for ideas that - because they do not have a foundation in the "nature" - require rebellion against "nature" even when such a "nature" appears as fiction and the result of natural sciences. An-acrhé leads politics to the achievement of what has traditionally metaphysically been named from Plato and Aristotle to Rousseau and Marx as the highest good in the community. It is not a concept of good as being opposed to the political community (politeia, civitas dei, republic, democracy). This is what has value in itself because it allows the freedom of all as individuals. No one rises to that as a member of the atomized society, but only as the political citizen and essential member of a democratic assembly of power that we call "people" (demos). Whoever nowadays would like to speak of a common good (communauté), knows so well that we are talking about something that is "privatized" and thus subdued in its "essence". All the newness of Rancière's notion of politics can be reduced to two irreducible opposites. Moreover, separation cannot be completely overcome by the revolutionary-emancipatory politics of radical democracy. On one side we have the concept of politics as equality and on the other the term "police" as the order (regime). [40]

Hence, it might be clear that democracy cannot be the form of a state, as an oligarchy necessarily becomes the rule of law of this order. However, the problem arises when the state gets suspended/is overcome in something that has the features of post-imperial sovereignty without political people (demos). Understanding the police as a state policy, and politics as a subversive-emancipatory activity of a democratic struggle for equality takes on the feature of a hybrid idea of the leftist history. Here is the meeting point of the anarchism of Bakunin/Proudhon and Marx's critique of the limits of formal democracy of the bourgeois order in the capitalist society of the nineteenth century. Moreover, Rancière redefines virtually all concepts from the tradition of "political philosophy". The situation of today is changed insomuch that states at the level of territorial sovereignty no longer have the factual power. This power is deployed to over-nation-state institutions such as the European Union. The corporate power of "democratic oligarchies" is not represented in the form of a state, as it follows from Rancière's analysis in the book Hatred of Democracy. [41] It is the absolute power beyond that of the sovereign state. What would be the consequences of such a "post-national constellation", if we use Habermas's expression, the purpose (telos) and the objective of the egalitarian politics of emancipation of the people (demos) as a subject without the substance of this whole process of defense of the dignity of politics? Rancière defines politics as a polemical achievement. It does so because the "essence" of equality does not occur from and out of "nature". "Essence" is creatively developed in a contingent struggle against the hierarchical order of social privileges. When politics are determined as such, then it is obvious that it must have its craving (orexis), the driving mechanism, what makes politics at all an autonomous activity of subjectivity. In the texts, we do not encounter the elaboration of an idea that reminds us of the rehabilitation of the concept of practice in another meaning. This also applies to the theory and poiesis. The reason lies in the fact that Rancière rejects these ontologicalpolitical categories created from "above" in Plato's and Aristotle's thinking. Instead, he advocates against any "naturalization" of social injustice and inequalities.

Therefore, it seems appropriate to point to another paradox in his notion of the classic terms of "political philosophy". Namely, equality would not make sense if this term is not a partage of a particular entity in a "just" or "unfair" way. Every distribution, as it is already done in Aristotle's Nicomachean Ethics, designates a contingent act of decision on the governance within the political community. [42] We could mention here the differ tribal society of those who rise above the immediate "primitivism" of nature. So, the distributive justice rests on the sharing of the common good. But the notion of the common good (communauté) to which Rancière refers has represented a significant political concept of communion. The origins go back to Rousseau's thinking of Republican creation of the state. However, the Republic always protects the public good of citizens with all available means of the social order (police and army). On the other hand, Hobbes' theory of the state places the emphasis on authoritarian power that protects the private property of individuals. The difference is that the notion of the common good as a public good and authoritarian state (Leviathan), which controls conflicting individuals on the market, denotes the difference between revolutionary "etatism" and enlightened "liberalism". Of course, it is the French tradition that presumes the sovereignty of people born in the native 
nation as the nation, while the English tradition of constitutional monarchy is expressed as the term "depoliticized politics". Between the Republic and the monarchy, there are several different theories as well as practical relationships. In short, the common good is firmly defined by the boundary between what is neither the matter of the state nor the individual's possession. It actually allows the distinction between state and society (politics and economics). And the reason is that the sacrifice of the nation as demos and as ethnos (people) can never be a sacrifice for the corporate power for particular interests. The victim is offered to the altar of a politically articulated community (republics, nation-states). Therefore, the issue of the sense of secularized deity within Jacques Rancière's theory of politics is deployed in the sphere of the aesthetic policy of events. It could be named like an event of the emancipation of a collective subject ("observer"). In addition, like the subjecting of the "people" in the struggle versus the order of hegemony and domination of the oligarchy, as well as the struggle for that what is "nobody's" because it is "everyone's" passes into the request for the qualitative distribution of the common good (communauté).

When does politics really start? For Rancière, the answer is simple. Politics always start when the public or common good is called into question by the fact that its "privatization" or division is becoming a part of the oligarchic rule. Are we talking about the historical continuity of such a type of rule (police order) in Western societies of antiquity, the Middle Ages, the New Era to the neoliberal globalization a destiny, or a necessity? The answer might be yes and no. Yes, because politics in Greece appears in the sense of the defence of communion and cannot be in a subordinate position of ethics and economics. Not, because of the idea of common good does not mean any vision of the egalitarian Communism of poverty or some terrible version of totalitarianism like that of the Red Khmer. History for Rancière has represented a continuous discontinuity of events. All this trigger the conflict between what belongs to the logic of an-arché and arché. Instead of the linearity and necessity of "higher" in the historical "progress" from the antiquity to the global order of the information age, contingent interdependence and emerging network of events are in rule. [43] Let's repeat: politics begin by a crack or by subjugating of the logic of oligarchic power placed in the alliance of financial and political elites of society. For this reason, the argument of disagreement has been extended to the Edge of Politics and the Hatred of Democracy. And it should be as follows: democracy refers to politics as a form of emancipation, and the social order of power derives from the economy. The result of it is the inequality in the capitalist mode of production. Social relations, therefore, are not the fatalities of history. The ability to change the relationship circuit exists only if at the same time there is a subject "powerful" enough to perform a radical change of state. In this respect, it is obvious that the policy of emancipation cannot be "revolutionary" unless it overturns the foundations of the structural perversion of relations from which the "iron law" of the oligarchy inevitably emerges. The latter concept was used by sociologist Robert Michels in a completely different context of the emergence of party bureaucracy within the framework of modern representative democracy. But what is true for parties without which there exists no liberal democracy, applies also to the complete transformation of social relations in global capitalism. The struggle around the "empty centre of power" becomes continuous and ever-new. So, the shadow of politics and economics of the new era takes a perverted turn. Montesquieu in The Spirit of the Laws already saw that the spoilage of democracy begins when politicians begin to speak in the language of traders, and traders get used to justifying their power in the language of politicians.

If then, communion, community, and communal good (communauté) bring us to the purity of what constitutes the "essence" of politics, then it is no longer possible to pledge for any half-way solution. The "police order" of the necessity of managing complicated systems of technocratic oligarchy rule requires much more than cosmetic repair. But the problem with Rancière's metapolitics in their view of politics has been seen from the beginning to be a problem of the impossibility of political without the articulation of power. Equality without power remains unfulfilled by the demands of the "people" as temporary demos. Since the subject without substance in global capitalism cannot be constituted by any means other than subjecting to combat and action, it remains only important to see what kind of fight and action is at work. The right question of any post-foundationalist policy becomes no longer what "is" the essence of such a policy, but how is the direction of such a policy happening. It is obvious that the meaning of its rhetoric and performing discourse derives from the upcoming (l'avenir). But in contrast to Derrida, Lyotard, Deleuze and Badiou, in the thinking of Rancière, the utopian field of expectation has no mention of the messianic appeal. Moreover, his demand for absolute equality of all and for all is in the nearness of Foucault's politics of resistance. Due to the intervention in the practical field which exhausts in "actuality" and is repeated in that timing swirl, the present has the status of the event and not the empty time of the future. What is actually "happening" with the politics of emancipation is nothing other than an attempt to establish that which has not existed in its real size and dignity other than as an an-arché as the scale of every future democratic politics. That what has never existed and is since the beginning the subject of human aspirations - as well as Aristotle in Politics says that people in communities always strive for the highest good - might be precisely what in the age of the neoliberal oligarchy rule is fragmented as its pieces have become corporate ownership in the hands of a few individuals.

\section{Conclusion}

Rancière's rebellion within the limits of the democratic emancipation of the "people" as a demos is directed against the "liberal-democratic consensus". The people are, 
therefore, subjectified through cultural-political struggle and the action of the oppressed and humiliated, of all those thrown out of the game of the networked machine of capitalist globalization and state with limited sovereignty. But what if in this new uncanny framework any so-called revolution or emancipatory policy is already very restricted because it lives from the "mysticism" of the event of the egalitarian rebellion, and the absolute power of oligarchic rule in "the new world order" states cannot be hurt at all precisely because it is no longer a problem to reach the heights of democratic politics but to preserve the mystical common good that is relentlessly absorbed under the excitement of the effectiveness of governance for the benefit of the community of "democratic individualism"? Rancière's response through a series of paradoxes and aporias, with a multitude of redefined concepts from the "political philosophy" tradition, remains within yet another irreducible confines of the impossible. This is the area of self-limitation and self-founding in something that is without foundation. With that, its non-limitation is ultimately inoperable. Any policy of disagreement with origins in the blemish of human freedom and with that which creates a scandal by the very act of its existence is limited by the fact that equality without the power of one's own performance will ultimately remain what the notion is and points out. Emancipatory politics is, namely - as it is paradigmatically stipulated by Marx in his early text $O n$ the Jewish Question - a certain kind of reduction. [44] When the "people" (demos) are relieved of one form of discipline, when the Jews - within the limits of national emancipation are freed from the oppressive politics which does not recognize Jewishness on the national-religious grounds within the German nation-state, then this kind of political or civil emancipation is incomplete with regard to human incompleteness. It is particularly in relation to the universality of what belongs to the notion of humanity. Emancipation presents the notion of the incompleteness of freedom as conditions of equality of opportunity. But if the emancipation does not have the power of freedom in its bare reality as its purpose as it only to fights "against" the political order of inequality, then its actual reach remains on the level of weak struggles for this or that kind of already obsolete rights within the boundaries of a long-established and outdated God of the nation-state.

The problem is that the rule of oligarchy in real-world states possesses the structure of the network. This was best described by Deleuze and Guattari in A Thousand Plateaus. [45] That is where the uncanny problem with the politics at the age of nihilism arises. It is no longer credible if it invokes the unfulfilled principles of the democratic utopia of the world. The true politics of the equality must face what lies in its own bargain. And that is the powerful and chaotic anarché. The paradox and aporia are not that democracy and freedom are derived from this principle without principles. The scandal that rules in neoliberal oligarchy represents a confirmation of the same an-arché. For this reason, its archipolitics, para-politics and meta-politics are "the cunning of reason" of a perverted order of the world where the power of the "police" sets limits to the "politics" of freedom and not vice versa. Contemporary oligarchy is based in this an-archéic model of chaos and ambiguity in all its visible and invisible areas of action, from the management of the economy to marketing policy. Its aesthetics is exactly the one which requires an "emancipated observer", all that (un)controlled fury of the re-politicized art of which nothing remains other than the media drive of the technosphere in museums that no longer preserve this majestic common good (communauté). Instead, they're dealing with screams of the policy of the performative events and the protection of conceptual property rights of those who no longer "produce", as the aesthetical spacing of politics does not reach the threshold of the nihilistic collapsed world of "illusion", "experience" and "look". When the an-arché as the voice of the people becomes a trademark of "revolution" and "subversion" of the ruling discourse, that uncanny sublime thing remains absent. What is absent, with no utopias and without big words, in the strikingly poetic manner is being expressed by Pier Palo Pasolini in his poem To the Red Flag (Alla Bandiera Rossa):

For he who only knows your color, red flag, you must really exist, so that he can exist: he who was covered with scabs is covered with wounds, the laborer becomes a beggar, the Neapolitan a Calabrese, the Calabrese an African, the illiterate a buffalo or dog. He who hardly knows your color, red flag, won't know you much longer, not even with his senses: you who already boast so many bourgeois and working class glories, you become a rag again, and the poorest wave you.

\section{References}

[1] Marchart, Oliver (2010) Die Politische Differenz: Zum Denken des Politischen bei Nancy, Lefort, Badiou, Laclau und Agamben. Frankfurt/M: Suhrkamp.

[2] See Davis, Oliver (2010) Jacques Ranciere. Cambridge: Polity Press, and Marchart, Oliver (2011) The Second Return of the Political: Democracy and the Syllogism of Equality, in Paul Bowman and Richard Stamp (eds.), Reading Rancière. London-New York: Continuum. 129-131.

[3] Derrida, Jacques (2005) The Politics of Friendship. LondonNew York: Verso. 130. See Paić, Žarko (2013) The Community Without Conditions: Deconstruction of the Subject of Modern Politics in Freedom Without Power: Politics in the Networks of Entropy. Zagreb: White Wave. 393-432.

[4] See May, Todd (2008), The Political Thought of Jacques Ranciere: Creating Equality. Edinburgh: Edinburgh University Press.

[5] See Beistegui, Miguel de (1998) Heidegger \& the Political: Dystopias. London-New York: Routledge, and Young, Julian (1997) Heidegger, Philosophy, Nazism. New York: Cambridge University Press, Labarthe, Philippe Lacoue (1990) Heidegger, Art, and Politics. Cambridge, MA: Basil Blackwell. 
[6] See Meier, Heinrich (2006), Was ist Politische Theologie? in Jan Assmann, Politische Theologie zwischen Ägypten und Israel. Munich: Carl Friedrich von Siemens Stiftung. 7-23.

[7] Paić, Žarko (2015) Totalitarianism? Zagreb: Meandarmedia. 135-206.

[8] Rancière, Jacques (1995) Mésentente: Politique et la philosophie. Paris: Galilée. 43-67. Oliver Marchart in the instructive analysis of "political differences", that is, the political and policy appear in the contemporary debate on the issue of a new set of equality and freedom, showed exactly that Rancière unlike almost all other post-foundationalist theorists (Nancy, Lefort, Badiou and Agamben) does not explicitly make this difference (Marchart, Oliver, ibid. 132.) Instead of the notion of the political as the ontological event space of creating conditions for democracy shortly before the dialogue and discourse, Rancière uses the notion of politics, and instead of the traditional concept of politics comes to the center of the rather controversial term "police". Ranking or regimes, therefore, must always think of the social hierarchy of power within the state. It is the order of legislative, executive and judicial power as an administrative technology of ruling. That's what is Michel Foucault in lectures at the Collège de France in the late 1970s and 1982-1983. on the basis of extensive historical-genealogical analysis came to the notion of "governmentality" (gouvernmentalité), that is specific state and society of management technologies from a close-knit perspective of economics and politics. Rancière, in a different horizon of understanding this problem, thinks equally as Foucault. But he emphasizes that the meaning of "police" that assumes positive features of the legitimacy of the execution and the stability of the liberal-democratic order. It thus seems significant that the "police order" is not merely the preservation of capitalist production and social relations built on the ideology of free competition, the market, and individualism. It might be a transition from the internal sphere of action to the outside. At the time of the post-imperial order of hegemony in the world's history as it is the case with America today which led war against terrorism and "rogue states". These are not wars between nation-states. Now, we have a new police interventions in the global space of expanded sovereignty. See Chambers, Samuel A. (2011) The Politics of the Police: From Neoliberalism to Anarchism, and Back to Democracy, by Paul Bowman and Richard Stamp (eds.), Reading Rancière. London-New York: Continuum. pp. $18-43$.

[9] Rancière, Jacques (2014) Hatred of Democracy. London-New York: Verso. 72-73.

[10] Plato (2003) The Republic. London: Penguin Classic.

[11] Rancière, Jacques (2000) Le partage du sensible: esthétique et politique. Paris: La fabrique.

[12] See Doerr, Nicole, Between Habermas and Rancière: The Democracy of Political Translation, http://eipcp.net/transversal/0613/doerr/en

[13] Rancière, Jacques (2011) The Emancipated Spectator. London-New York: Verso.

[14] Ranciere, Jacques (2000) Le partage du sensible. See about criticism Rancière 's notion of politics in the text by Žižek, Slavoj (2004) "The Lesson of Rancière: Afterword", in Jacques Rancière, The Politics of Aesthetics. London-New York; Continuum. 69-79.

[15] Rancière, Jacques (1995) Mésentente. 93-131. See Bosteels,
Bruno (2010) Archipolitics, Parapolitics, Metapolitics, in Deranty, Jean-Philippe Jacques Rancière: Key Concepts. Durham: Acumen. 80-92.

[16] Rancière, Jacques (1998) Dix Theses sur la politique, in $\mathrm{Au}$ bords du politique. Paris: Gallimard. 22.

[17] Rancière, Jacques, ibid. 223.

[18] Mouffe, Chantal (2006) The Return of the Political. LondonNew York: Verso, and Ernesto Laclau (1996), Emancipation (s). London-New York: Verso.

[19] Rancière, Jacques (1999) Disagreement: Politics and Philosophy. Minneapolis-London: University of Minnesota Press. 9-10 and 19.

[20] Badiou, Alain (1998) Abrégé de métapolitique. Paris: Seuil, and Badiou, Alain (2008) Philosophy and Politics in Conditions. London-New York: Continuum. 147-176.

[21] Sartre, Jean-Paul (1943) L'etre et le Néant: Essai d'ontologie phénoménologique. Paris: Gallimard.

[22] Aristotle (2000) Politics. London: Penguin Classics.

[23] Rancière, Jacques (1995) Mésentente. 11.

[24] See Paić, Žarko (2013) Freedom Without Power: The Politics in Networks of Entropy. 20-62.

[25] Rancière, Jacques (1998) Aux bords du politique. 65-66 and 225-226.

[26] Rancière, Jacques (1995) Mésentente. 93-131.

[27] Althusser, Louis (1962) Pour Marx. Paris: F. Maspero.

[28] Sartre, Jean-Paul (1960) Critique de la raison dialectique: Théorie des ensembles pratiques précéde de Question de methode, Vol. I. Paris: Gallimard.

[29] Rancière, Jacques (1974) La Leçon 'd'Althusser. Paris: Gallimard, and Rancière, Jacques (1987) La Maitre Ignorant : Cinq Lessons of the Émancipation Intellectuelle. Paris: Fayard.. See more in Davis, Oliver, ibid. 1-73.

[30] Lyotard, Jean-François (1988) The Differend: Phrases in Disput. Minneapolis: University of Minnesota Press.

[31] Rancière, Jacques (1995) Mésentente. 7-8.

[32] Rancière, Jacques (1995) Mésentente. 69-91.

[33] See McCarthy, Thomas (1994) Kantian Constructivism and Reconstructivism: Rawls and Habermas in Dialogue, Ethics. No. 105. 44-63

[34] See Hewlett, Nick (2007) Badiou, Balibar, Rancière : Rethinking Emancipation. London-New York: Continuum. 84115 .

[35] Rancière, Jacques (1998) Aux bords du politique. 157-158.

[36] Badiou, Alain (2010) A Communist Hypothesis. London-New York: Verso.

[37] Chambers, Samuel A., ibid.18.

[38] Lefort, Claude (1981) L'invention démocratique: Les limits de la domination totalitaire. Paris: Fayard.

[39] Rancière, Jacques (1995) Mésentente. 167-187. 
[40] A strong separation of politics and police (le politique and la politique) goes so far that one can often get the impression of man's understanding of the world in secular Christian "good" and "evil" categories. But between these two concepts, the government is mutually conditional. We can here accept the interpretation of Oliver Marchart, who argues that the policy of disagreement and disagreement stands above the existence of "two worlds in one" but is subject to what is termed as "emancipatory apriorism." This means that equality is not only a prerequisite of democratic political action, a prerequisite of its contradiction - the police order. If, then, the idea of a policy contained in the concept of equality, then this term appears almost as the "grounding unfoundation" of democratic rebellion against the order and has revolutionary potential. In this way, Marchart can conclude that it is within the postfoundationalist theory of politics Rancière 's attempt to think politics from the principle of an-arché is nothing other than the path to a-historical conditions. So, this means that the political struggle against "regimes" has the status of "transcendental conditions" of egalitarian politics. - Marchart, Oliver (2011) The Second Return of the Political. 134-135.
[41] Rancière, Jacques (2014) Hatred of Democracy. 71-97.

[42] Aristotle (2012) Nicomachean Ethics. Chicago: University of Chicago Press.

[43] See Thomson, Alex (2011) "On the Shores of History", by Bowman, Paul and Stamp, Richard (eds.) Reading Rancière. London-New York: Continuum. 200-2016.

[44] Marx, Karl (1976) Zur Judenfrage, in Marx, Karl and Engels, Friedrich, MEW, vol. I. Berlin: Dietz. 347-377.

[45] Deleuze, Gilles and Guattari, Felix (1987) A Thousand Plateaus: Capitalism and Schizophrenia II. Minnesota: University of Minnesota Press. 